Primljen / Received: 11.7.2018. Ispravljen / Corrected: 25.10.2018.

Prihvaćen / Accepted: 11.3.2019.

Dostupno online / Available online: 10.5.2020.

\section{Fuzzy multicriteria decision-making in} railway infrastructure planning and design

Autori:

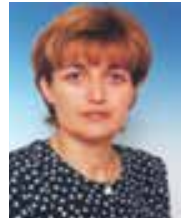

'Assist.Prof. Milana Kosijer m.kosijer@sf.bg.ac.rs

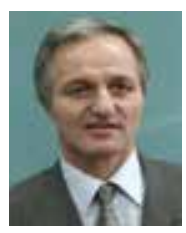

Prof. Miloš Ivić

m.ivic@sf.bg.ac.rs

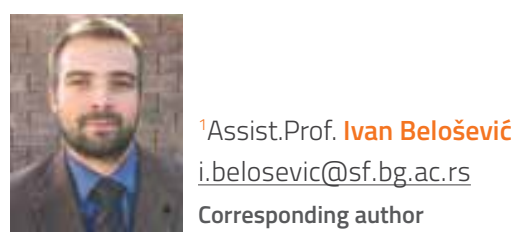

${ }^{1}$ Assist.Prof. Norbert Pavlović norbert@sf.bg.ac.rs

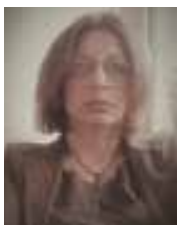

${ }^{2}$ Marija Opricović, dipl.eoc. marija.opricovic@nbs.rs

${ }^{1}$ University of Belgrad, Serbia Faculty of Transport and Traffic Engineering

${ }^{2}$ National Bank of Serbia

\section{Milana Kosijer, Miloš Ivić, Ivan Belošević, Norbert Pavlović, Marija Opricović}

Research paper

\section{Fuzzy multicriteria decision-making in railway infrastructure planning and design}

A fuzzy multicriteria approach in the railway infrastructure planning and design, enabling an integrated and systematic solving of uncertainty and indeterminacy problems in the evaluation of criteria functions, is presented in paper. The proposed multicriteria decision making approach is presented in the scope of the methodology for selecting the most favourable route of a double track railway. Triangular fuzzy numbers are used to evaluate variant solutions, while the VIKOR fuzzy method is used for route ranking.

Key words:

railway infrastructure, planning and design, multicriteria decision-making, fuzzy VIKOR method

Prethodno priopćenje

Milana Kosijer, Miloš Ivić, Ivan Belošević, Norbert Pavlović, Marija Opricović

\section{Neizrazito višekriterijsko odlučivanje u planiranju i projektiranju željezničke infrastrukture}

U radu je prikazan pristup neizrazitog višekriterijskog odlučivanja u procesu planiranja i projektiranja željezničke infrastrukture koji omogućava cjelovito i sustavno rješavanje problema postojanja faktora neizvjesnosti i neodređenosti prilikom procjene vrijednosti kriterijskih funkcija. Predloženi pristup višekriterijskog odlučivanja je predstavljen u okviru metodologije za izbor najpovoljnije trase dvokolosiječne željezničke pruge. Za vrednovanje varijantnih rješenja trase u radu su upotrebljeni trouglasti neizraziti brojevi, a za rangiranje je primijenjena neizrazita VIKOR metoda.

Ključne riječi:

željeznička infrastruktura, planiranje i projektiranje, višekriterijsko odlučivanje, neizrazita VIKOR metoda

Vorherige Mitteilung

Milana Kosijer, Miloš Ivić, Ivan Belošević, Norbert Pavlović, Marija Opricović

Vage Entscheidungsfindung nach mehreren Kriterien bei der Planung und Projektierung der Eisenbahninfrastruktur

In der Abhandlung wird ein Ansatz der vagen Entscheidungsfindung nach mehreren Kriterien im Prozess der Planung und Projektierung der Eisenbahninfrastruktur präsentiert, der eine vollständige und systematische Lösung des Problems des Vorhandenseins von Unwägbarkeits- und Unbestimmbarkeitsfaktoren bei der Beurteilung des Wertes der Kriteriumsfunktionen ermöglicht. Der vorgeschlagene Ansatz der Entscheidungsfindung nach mehreren Kriterien wird im Rahmen der Methodik für die Auswahl der günstigsten Trasse der zweigleisigen Eisenbahnstrecke vorgestellt. Für die Bewertung der Lösungsvarianten der Trasse wurden in der Abhandlung dreieckige vage Zahlen und für die Festlegung der Rangfolge wurde die vage VIKOR Methode verwendet.

Schlüsselwörter:

Eisenbahninfrastruktur, Planung und Projektierung, Entscheidungsfindung nach mehreren Kriterien, vage VIKOR Methode 


\section{Introduction}

Railway infrastructure planning and design is based on important decisions that must be taken to solve many issues related to the construction of new or reconstruction of the existing facilities. After defining problems and generating variant solutions, these variant solutions are evaluated and the most favourable one is selected. Although technical accuracy and cost efficiency are important aspects, they are not the only imperative for the evaluation of projects in the comprehensive field of transport infrastructure. During evaluation of variant solutions, it is necessary to consider their exploitation characteristics and functionality, as well as their wider socioeconomic context, while also taking into account various external effects. The external effects of infrastructure projects may be positive and negative. Positive external effects include establishment of traffic connections and contribution to an overall economic development of the region, while negative external effects include the risk of fatal traffic accidents, disruption of coherent development of spatial structures, and detrimental environment impacts.

In such circumstances, it is appropriate to develop and apply multiattribute decision making methods and/or multicriteria analysis methods thathaveproven to besuitablefor solving decision-making issues. By applying multicriteria analysis methods, problems are solved by identifying the best or the least harmful variant, or a set of good variants, based on the defined criteria and their weights. Within the defined set, some criteria are quantitative, while some are qualitative. Also, some criteria should be maximized, and some have to be minimized. Since the criteria are mutually inconsistent and expressed in various units of measure, decisions are made in conflicting circumstances.

Among numerous multicriteria analysis methods, the AHP method (Analytic Hierarchy Process), PROMETHEE (Preference Ranking Organization METHod for Enrichment Evaluation), ELECTRE (in French: ELimination Et Choix Traduisant la REalite), and VIKOR (in Serbian: VIšeKriterijumska Optimizacija i KOmpromisno Rešenje or in English: Multicriteria Optimisation and Compromise Solution), have been identified as methods that have been applied for solving real-life problems of evaluating variant solutions for railway or road infrastructure projects [1-6]. By applying the aforementioned methods, the problem of decision-making is modelled by assuming the certainty of the attribute, i.e. an already defined set of acceptable variant solutions and precisely defined criteria and criteria functions. On the other hand, the decision-making problem in evaluating variant solutions in railway or road infrastructure projects is most often characterized by the criteria that cannot be clearly quantified by a criterion function and represented with a numerical value for each variant solution. In fact, this decisionmaking problem includes a factor of uncertainty and indeterminacy in assessing the value of criteria functions. The existence of uncertainty and indeterminacy factors has been confirmed by results of ex-post analyses of large infrastructure projects [7], which points to significant imprecisions in the calculation of overall effects of such projects. The results of these research activities are based on the comparison between estimated values obtained in the project design process and actual results obtained after project implementation and commissioning.

The said factor of uncertainty and indeterminacy has motivated us to propose a new approach to multicriteria decision-making in the sphere of railway infrastructure planning and design. The model of multicriteria decision-making, applied in the methodology for evaluating and selecting the most favourable route for the railway line [6], is based on the traditional VIKOR method. The newly proposed method of multicriteria decisionmaking in the railway infrastructure planning and design upgrades the aforementioned model with the theory of fuzzy sets [8], i.e. by the fuzzy VIKOR method. The theory of fuzzy sets is an effective way to mathematically define the uncertainties and indeterminacies present in dealing with problems that are either complex by their nature, or poorly defined and structured. The proposed fuzzy multicriteria approach ensures representation of uncertain attributes by fuzzy numbers. By introducing the theory of fuzzy numbers into the multicriteria analysis, the identified shortcomings of traditional multicriteria methods can be overcome and, therefore, more reliable results can be achieved.

The applicability of the newly presented method of multicriteria decision-making in the planning and design is shown on an example of a railway route. The analysed example involves selection of the double-track railway route on a Corridor Xb section between Indija and Novi Sad railway stations. The Corridor Xb is included in the Basic Trans-European Transport Network in the Western Balkans (TEN-T Core Network in Western Balkans) and is designated as an extension of the East/East Mediterranean Corridor (Orient/ East-Med Corridor). The efficiency of the newly presented method was verified by comparing the results with those obtained using a traditional multicriteria method.

\section{Literature review}

The basic approach in the analysis and assessment of infrastructure projects is based on the application of economic evaluation criteria. During economic evaluation of infrastructure projects, the methods of cost-benefit analysis, net present value, or internal rate of return, are most commonly used. In the economic evaluation of projects, the highest emphasis is on evaluation of alternative solutions expressed in monetary units. Disadvantages of such an approach primarily lie in the inability to monetize all project benefits and variant solutions. These shortcomings and limitations in the application of purely economic evaluation of projects in the field of transport and traffic infrastructure are presented in greater detail in a number of papers, such as in [9-11].

Taking into account a wider socio-economic context of infrastructure projects, dominated by various external effects such as positive impacts on population mobility and economic development, or negative impacts on spatial structures and the environment, it becomes clear that additional approaches should be development for proper analysis and assessment of such projects. In this regard, the methods of multicriteria analysis can be applied in situations when 
Table 1. Application of multicriteria analysis for ranking variant solutions in transport infrastructure

\begin{tabular}{|c|c|c|}
\hline Literature and year of publication & Problem description & Method used \\
\hline$[20], 2000$ & Highway route selection & AHP \\
\hline$[25], 2003$ & City bypass route selection & Bayes model of compromise programming \\
\hline$[5], 2004$ & Railway route selection & AHP \\
\hline$[1], 2006$ & City railway corridor selection & ANP \\
\hline$[21], 2010$ & City railway corridor selection & VIKOR \\
\hline$[6], 2012$ & Railway route selection & ELECTRE \\
\hline$[24], 2015$ & Railway route selection & AHP i TOPSIS \\
\hline$[3], 2015$ & Local road design selection & AHP \\
\hline$[22], 2016$ & City railway route selection & PROMETHEE \\
\hline$[2], 2016$ & State road design selection & AHP \\
\hline$[4], 2017$ & Railway route selection & VIKOR \\
\hline$[23], 2018$ & Road-rail intersection design selection & Railway route selection \\
\hline$[26], 2018$ & P & \\
\hline
\end{tabular}

choice should be made between several variant solutions based on a number of multi-dimensional, quantitative, and qualitative criteria. An overview of the literature on the first applications of multicriteria analyses in the field of traffic and transport infrastructure planning is given in $[12,13]$. The application of multicriteria analysis in this area started in the 1970s with papers [14, 15] and was subsequently intensively developed in the 1980s through a number of papers, such as [16-19]. Among these papers, the paper [16] represents the first research on the ranking of variants for linear infrastructure routes. Ranking of variants for the metro network extension in Paris based on the ELECTRE method is presented in paper. The ranking was carried out on 12 variant solutions, based on the following six criteria: density of population in the metro line gravity zone, estimated number of attracted passengers, investment cost, socioeconomic rate of return of the project, impact on overall organization of the public transport system, and impact on further urban development of this metropolis.

Further research in the field of ranking variant solutions for railway and road infrastructure projects was carried out using various multicriteria analyses. A chronological summary of these research incentives is given in Table 1.

The AHP method is the most widely used multicriteria analysis method. In paper [20] the AHP method was used to rank five variant solutions for a highway route in South America. Also, the AHP method was applied in paper [1] for selection of the most favourable light rail corridor in Memphis (Texas, USA), while in paper [21] the same example was used to analyse the application of the ANP method (Analytic Network Process) as a non-linear form of the AHP method. A hybrid model combining the AHP and TOPSIS methods (Technique for Order Preference by Similarity to Ideal Solution) ) is proposed in paper [22] for selecting the mono-rail system in Ankara (Turkey. The AHP method was used in papers [2, 23] to model decision-making problems in designing a section of the state road D8 (Adriatic Highway), i.e. in designing the road/railway crossing Trnava in Zagreb (Croatia).
In addition to AHP method, the literature includes a number of papers in which other multicriteria analysis methods were applied. For example, the ELECTRE method was applied in papers [5, 24] for selecting the most favourable railway route. The authors of these papers analysed the applicability of this method on high-speed train routes in Spain and Malaysia.

Compromise ranking methods were applied in papers [6, 25]. The Bayes model of decision-making was applied in paper [25] for ranking five variants of the main ring-road around Madrid, while the VIKOR method was used in paper [6] for ranking 4 variants of the main railway section route in Serbia. The VIKOR method based on linguistic assessments was used in paper [26] to evaluate variant solutions at an early stage of an infrastructure project.

The PROMETHEE method was applied in papers [3,4]. The evaluation and ranking of variant solutions of the secondary road network, with a special emphasis on safety criteria, was performed in paper [3]. The possibility of establishing railway connection between the ports of Trieste, Koper and Rijeka, and further with the Mediterranean corridor of the TEN-T network, when ranking variant rail route solutions, was analysed in paper [4].

A special attention was paid in papers $[3,6,25]$ to the procedure for evaluating variant solutions by defining criteria functions for an objective quantification of a list of criteria. An approach based on subjective assessment by experts was applied in papers $[4,26]$.

Recent research efforts are increasingly based on the GIS (Geographic Information System) technology and are aimed at creating the SDSS system, i.e. the Spatial Decision Support System. SDSS systems are characterized by automation of the data collection and processing process, and by the ability to visualize variant solutions and the results of their evaluation. For example, in paper [27], an SDSS system was introduced for generating and evaluating the Baltic corridor variants passing through Poland within the TEN-T network. Also, the SDSS system was created in paper [28] for selecting the most favourable railway routes within the high speed train network that connects the cities of Houston, Dallas, San Antonio, and Austin, with 
the Texas Urban Triangle zone (USA). A comprehensive overview of literature on the application of multicriteria analysis methods in the field of transport infrastructure is given in paper [29] and also in review papers focusing on the field of the theory of decision-making, as applied in construction [30-32].

\section{VIKOR method in fuzzy environment}

The newly proposed approach to multicriteria decision-making in the planning and design of railway infrastructure is based on the application of VIKOR methods in a fuzzy environment. In this regard, this section gives a brief overview of the VIKOR method and the theory of fuzzy sets. The VIKOR method developed for multicriteria decision-making and based on compromise programming will be presented first. After that, the postulates of the theory of fuzzy sets will be presented and basic operations with fuzzy numbers will be defined.

\subsection{VIKOR method}

The VIKOR method was developed as a multicriteria decisionmaking method (VKO) for resolving discrete problems with conflict and heterogeneous criteria [33]. The method is based on compromise programming as an acceptable approach for overcoming these conflicts and diversity among the established criteria. VIKOR method characteristics are discussed in greater detail in papers [34, 35]. In addition to a detailed presentation of the method's theoretical basis, a comparison of the VIKOR method efficiency as related to the efficiency of several other multicriteria analysis methods was performed in these papers. The VIKOR method ranks variants and determines a compromise solution. Since in most cases there is no variant that would be at the same time the best and the most favourable according to all criteria, this method looks for an acceptable solution that is closest to the ideal solution in the area covered by criteria functions. The solution that is "closest to" an ideal one is called a compromise solution based on the adopted deviation criteria. The "limit" measures $L_{p}$ of the compromise programming metrics are used to measure deviation from an ideal solution [36]:

$$
L_{j}^{p}=\left\{\sum_{i=1}^{n}\left[\frac{w_{i}\left(f_{i}^{*}-f_{i j}\right)}{f_{i}^{*}-f_{i}^{-}}\right]^{p}\right\}^{1 / p} 1 \leq p \leq \infty
$$

where:

$f_{i j} \quad$ - the value of $\mathrm{i}$-criteria function for j-variant solution, $i=1, \ldots, n \mathrm{i} j=1$, $\ldots, m$

$f_{i}^{*} i f_{i}^{-}$- the best and the worst value of the criteria function

$w_{i} \quad$ - weight coefficients of selected criteria, $w_{i} \geq 0$.
The solution obtained by minimizing the measure $L_{j}^{1}$ (in the VIKOR method designated as QS) is a variant that provides maximum total utility as per all criteria, while the solution obtained by minimizing the measure $L_{j}^{\infty}$ (in the VIKOR method designated as $Q R$ ) represents a variant which provides maximum individual deviation as per one of the criteria. The ranking lists obtained by measures $L_{j}^{1}$ and $L_{j}^{\infty}$ most often differ from each other, therefore a procedure has been proposed for determining a single consolidated ranking list. This ranking list is obtained by consolidating the measures $L_{j}^{1}$ and $L_{j}^{\infty} u$ sing the weighting factor of the decision-making strategy $\vartheta$. The solution obtained by minimizing the consolidated measure represents a compromise between the maximum total utility and the maximum individual deviation. The solution obtained in this way can beaccepted or can be the basis for further negotiations based on a narrow set of variant solutions that approach the ideal solution, which are by their values, situated within the area of criteria functions.

\subsection{Theory of fuzzy sets}

The theory of fuzzy sets [8] is formulated with the aim to adequately solve problems involving the factor of uncertainty. Unlike the classic theory of sets based on the fact that an element may belong or may not belong to a set, the theory of fuzzy sets allows the partial membership of an element to a set. As a result, the theory uses fuzzy numbers that by their function of membership mathematically express the level of uncertainty or inaccuracy of certain events. Although there are many forms of fuzzy numbers, among which triangular, trapezoidal and Gaussian numbers are most often applied in the literature [3739], triangular numbers have been used in this paper. Triangular numbers were selected to show uncertainty when evaluating railway infrastructure projects due to their simple membership function of a linear type (Figure 1):

A triangular fuzzy number can be defined as a triplet of real numbers $\tilde{A}=\left(a_{n}, a_{m^{\prime}} a_{r}\right)$, where $a \leq a_{m} \leq a_{r}$. The parameter designates the lowest possible value, the parameter $a_{m}$ the most promising value (modal value), while the parameter $a$ designates the highest possible value that describes a fuzzy number. The value of the membership function $\mu_{\tilde{A}}(x)$ represents the level of membership of an element $x$ to the set $\tilde{A}$, so that the higher value $\mu_{\tilde{A}}(x)$ designates a greater-level membership of the

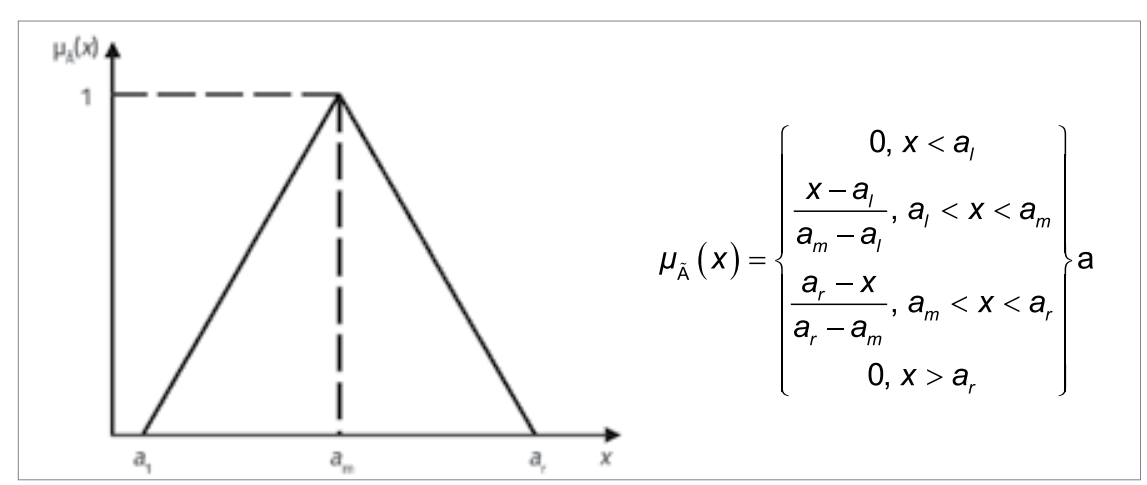

Figure 1. Triangular fuzzy number $\tilde{A}$ 
element $x$ to the set $\tilde{A}$. Basic operations on triangular numbers $\tilde{A}$ $=\left(a, a_{m^{\prime}}, a\right)$ and $\mathrm{B}=\left(b_{1}, b_{m^{\prime}}, b_{r}\right)$ are defined by the following expressions (2) to (7):

$$
\begin{aligned}
& \tilde{\mathrm{A}}+\tilde{\mathrm{B}}=\left(a_{l}+b_{1} a_{m}+b_{m^{\prime}} a_{r}+b_{r}\right) \\
& \tilde{\mathrm{A}}-\tilde{\mathrm{B}}=\left(a_{l}-b_{r} a_{m}-b_{m^{\prime}} a_{r}-b_{r}\right) \\
& \tilde{\mathrm{A}} \cdot \tilde{\mathrm{B}}=\left(a_{l} \cdot b_{r} a_{m} \cdot b_{m^{\prime}} a_{r} b_{r}\right) \\
& \mathrm{k} \cdot \tilde{\mathrm{A}}=\left(k \cdot a_{r} k \cdot a_{m^{\prime}} k \cdot a_{r}\right) \\
& \max (\tilde{\mathrm{A}}, \tilde{\mathrm{B}})=\left(\max \left(a_{r} b_{l}\right), \max \left(a_{m^{\prime}} b_{m}\right), \max \left(a_{r}, b_{r}\right)\right) \\
& \min (\tilde{A}, \tilde{B})=\left(\min \left(a_{r}, b_{l}\right), \min \left(a_{m^{\prime}} b_{m}\right), \min \left(a_{r}, b_{r}\right)\right)
\end{aligned}
$$

The transformation of fuzzy numbers into appropriate traditional numbers is performed by defuzzification. In the aforementioned literature [37-39] several different methods for defuzzification may be found, such as the centre of the maximum, the mean of the maximum, the centroidal method, etc. In this paper, the method of weighted environment has been applied [40] for the value of parameter $k=1$ :

$x_{0}(\tilde{A})=\left(a_{1}+k a_{m}+a_{r}\right) /(k+2)$

In the case of parameter $\mathrm{k}=1$, this method obtains the form of a centroidal method that interprets the crisp value of the number as the focus (centre of mass):

$\mathrm{x}_{0}(\tilde{\mathrm{A}})=\left(\mathrm{a}_{1}+\mathrm{a}_{m}+\mathrm{a}_{\mathrm{r}}\right) / 3$

\section{Proposed fuzzy approach of multicriteria decision-making}

The fuzzy VIKOR method forms the basis of the proposed approach to multicriteria decision-making. The fuzzy VIKOR method [40, 41] was developed as a fuzzy VKO method in order to solve a discrete multicriteria problem with heterogeneous and conflicting criteria, as well as with the criteria that cannot be clearly quantified and shown by a single numerical value. Therefore, within the model of estimating and evaluating variant solutions $V(j=1,2, \ldots, m)$ according to relevant criteria $K(i=1,2, \ldots, n)$, it is realized via triangular fuzzy numbers $f_{i j}=\left({ }_{i j} m_{i j} r_{i j}\right)$. The selection of criteria that are relevant for the evaluation of variant solutions is carried out on the basis of some general objective that a railway infrastructure needs to achieve after being constructed, i.e. during it service life. For this reason, an overall objective includes economic, technical, technological, traffic and exploitation and spatial-ecological aspects of the construction and use of a railway infrastructure. The selected criteria can be classified into the criteria of the maximizing criteria functions represented by the set $k^{\circ}$ and the criteria characterized by the minimizing criteria functions represented by the set $\kappa$.

The fuzzy VIKOR method algorithm consists of the following steps:
Step 1: Selection of the best $\tilde{f}_{i}^{*}=\left(l_{i}^{*}, m_{i}^{*}, r_{i}^{*}\right)$ and the worst $\tilde{f}_{\mathrm{i}}^{-}=\left(l_{i}^{-}, m_{i}^{-}, r_{i}^{-}\right)$values of the criteria functions:

$\tilde{f}_{i}^{*}=\max _{j} \tilde{f}_{i j}, \tilde{f}_{i}^{-}=\min _{j} \tilde{f}_{i j}$ for $i \in K^{b}$

$\tilde{f}_{i}^{*}=\min _{j} \tilde{f}_{i j}, \tilde{f}_{i}^{-}=\max _{j} \tilde{f}_{i j}$ for $i \in K^{c}$

Step 2: Determining a normalized value of the fuzzy measure $\tilde{d}_{i j}$ $, j=1,2, \ldots, m, i=1,2, \ldots, n$

$\tilde{d}_{i j}=\frac{\tilde{f}_{i}^{*}-\tilde{f}_{i j}}{r_{i}^{*}-l_{i}^{-}} \quad$ for $i \in K^{b}$

$\tilde{d}_{i j}=\frac{\tilde{f}_{i j}-\tilde{f}_{i}^{*}}{r_{i}^{-}-l_{i}^{*}} \quad$ for $i \in K^{c}$

Step 3: Determining the value of the fuzzy measure of deviation $\tilde{S}_{j}=\left(S_{j}^{\prime}, S_{j}^{m}, S_{j}^{r}\right)$ and $\tilde{R}_{j}=\left(R_{j}^{\prime}, R_{j}^{m}, R_{j}^{r}\right), \mathrm{j}=1,2, \ldots, \mathrm{m}$ of variants from an ideal solution:

$\tilde{S}_{j}=\sum_{i=1}^{n}\left(\tilde{w}_{i} \cdot \tilde{d}_{i j}\right)$

$\tilde{R}_{j}=\max _{i}\left(\tilde{w}_{i} \cdot \tilde{d}_{i j}\right)$

where $\tilde{w}_{i}$ is the fuzzy weight coefficient of the selected criteria.

Step 4: Determining the value of the fuzzy measure of deviation $\mathrm{Q} \tilde{Q}_{j}, j=1,2, \ldots, m$ of variants from an ideal solutions:

$\tilde{Q}_{j}=\frac{\vartheta\left(\tilde{S}_{j}-\tilde{S}_{j}^{*}\right)}{S^{-r}-S^{*}}+\frac{(1-\vartheta)\left(\tilde{R}_{j}-\tilde{R}_{j}^{*}\right)}{R^{-r}-R^{* I}}$

or abbreviated:

$\tilde{Q}_{j}=\vartheta \widetilde{Q S_{j}}+(1-\vartheta) \widetilde{Q R}$

where $\tilde{S}_{j}^{*}=\min \tilde{S}_{j}, \tilde{S}_{j}^{-}=\max \tilde{S}_{j}, \quad \tilde{R}_{j}^{*}=\min \tilde{R}_{j}, \tilde{R}_{j}^{-}=\max \tilde{R}_{j}$ and $\vartheta \mathrm{s}$ the weight of the décision-making strategy by the "majority of criteria", whose values are within the interval $(0,1)$.

Step 5: Defuzzification of the value $\widetilde{Q S_{j}} \widetilde{Q R_{j}} \mathrm{i} \tilde{Q}_{j}$ by applying the relation (9).

Step 6: The creating of ranking lists for defuzzified value of the measure of deviationa $Q S, Q R$ and $Q_{j}$. Ranking is performed based on the decreasing values for each of the deviation measures

Step 7: The proposal of a compromise solution and reaching final decision on the most favourable variant solution. In order to ensure that a variant solution can be proposed as the most favourable one, it is necessary, in addition to being the first in the ranking list as per measure $Q$, that this solution meets the requirements of "sufficient advantage" (requirement U1) and "'sufficient stability" (requirement U2) [33]. 
The requirement of "sufficient advantage" allows that the decision maker be presented with all variant solutions that are "close" in multicriteria terms. It would not be justified that only one variant, ranked first as per measure $Q$, be shown to the decision maker and that variants with a "close" value $Q$ be ignored. The firstranked variant $V^{(1)}$ will have sufficient advantage over the secondranked variant $\mathrm{V}^{(2)}$ if the following inequality is satisfied:

$$
Q\left(V^{(1)}\right)-Q\left(V^{(2)}\right) \geq D Q, D Q=\min \left(0,25 ; \frac{1}{m-1}\right)
$$

- First position in the ranking list as per Q for $\vartheta=0,25$ and $\vartheta=0,75$,

- First position in the ranking list as per QS,

- First position in the ranking list as per QR.

\section{Example of railway route selection in fuzzy environment}

Railway lines are complex transport infrastructure facilities and their construction or reconstruction require great investments. On the other hand, the implementation of modern transport system development concepts and long-term plans for the improvement of railway networks requires application of latest solutions in the sphere of design and technology. Taking all this into account, it is very important to select the most favourable variant solution when designing and evaluating railway line route solutions, while also ensuring respect of modern traffic infrastructure quality criteria. The most favourable variant solution of the route itself is selected through an iterative optimization process. This process is derived from the fact that railways belong to a set of discrete systems [33], which means that a comprehensive mathematical model cannot be formulated for their description, but that a number of variant solutions of the railway route must be generated through an iterative optimization process. The following activities are included in the iterative optimization process: generation of variant solutions $K_{f}$ establishment of the list of relevant criteria and criteria evaluation functions, and individual evaluation of each variant as per each criterion in which the value of the criteria function is determined for each variant. In the event that a criterion cannot be clearly quantified and expressed by a numerical value, the criteria function is expressed by a triangular fuzzy number $f_{i j}=\left(l_{i j} m_{i, j} r_{i j}\right)$. The last activity in this process is the ranking of variant solutions. The result of the ranking is the ranking list in which the order of variant solutions is given (if there are several weight coefficient scenarios, the ranking list is ranked for each scenario). The final selection and decision on the most favourable variant of the railway route is made based on this ranking list. The most favourable variant can be either the finally selected variant or a narrowed-down set (shortlist) of variant solutions.

The fuzzy approach to multicriteria decision-making proposed in this paper was tested on the new route design for the doubletrack railway line on the section between Inđija and Novi Sad train stations [42]. This section is a part of Corridor Xb that passes through the Republic of Serbia, and is included in the Basic TEN-T network of the Western Balkans.

\subsection{Generation of route variants}

Variant solutions for the new railway line between Indija and Novi Sad train stations were generated:

- by varying basic technical (structural and operational) elements of the route,

- by fitting and adapting the route to: the existing and planned spatial structures, positions of cultural and historical heritage sites and protected areas,

- based on in situ, geological and hydrological conditions of the immediate surroundings.

Given the arrangement of spatial structures (existing settlements, Fruška gora National Park, Sremski Karlovci cultural monument, protected marshes, and the Danube River) and very complex geological indicators of the terrain along the section between Inđija and Novi Sad stations (Čortanovačko klizište landslide), the following two basic directions of a new route have been identified:

The first one, which mostly follows the existing Indija - Novi Sad railway route, and separates from it in the "Čortanovačko klizište" zone between Beška and Sremski Karlovci. Several variant solutions have been developed for this corridor.

The second one, which leaves the existing railway line corridor in front of Beška station, crosses the Danube River and, running parallel to the E75 Belgrade-Novi Sad motorway, accesses Novi Sad from the east, and enters this city by crossing the DanubeTisa-Danube channel.

From the set of generated solutions, four permissible variant solutions of the railway line route (Figure 2 ) were selected and included in further iterative optimization procedure. Out of these solutions, three are located along the right and one along the left bank of the Danube River. Basic characteristics of these solutions are:

- Variant $\mathbf{V}_{\mathbf{1}}$ - Čortanovci: from Inđija to Beška it runs along the existing railway and then turns towards higher slopes of Fruška gora, from where it descends to Sremski Karlovci and Petrovaradin and enters the Novi Sad station via the new bridge over the Danube. The length of this route is $32,455 \mathrm{~km}$.

- Variant $\mathbf{V}_{\mathbf{2}}$ - Maradik: after Inđija station it immediately leaves the corridor of the existing railway and turns towards Maradik, then descends towards Petrovaradin, with three tunnels passing through the slopes of Fruška gora. Novi Sad station is accessed via the new bridge over the Danube, the same as for the Čortanovci variant. The length of this route is $32,010 \mathrm{~km}$.

- Variant $\mathbf{V}_{\mathbf{3}}$ - Combined: from Inđija station to Čortanovci station, the route runs along the Čortanovci variant; then it turns left towards the slopes of Fruška gora and near Sremski Karlovci it integrates with the Maradik variant. The length of this route is $32,605 \mathrm{~km}$. 
Table 2. Characteristics of variant solutions

\begin{tabular}{|c|c|c|c|c|}
\hline \multirow{2}{*}{ Route characteristics } & \multicolumn{4}{|c|}{ Variant solution } \\
\cline { 2 - 5 } & $\mathbf{V}_{\mathbf{1}}$ & $\mathbf{V}_{\mathbf{2}}$ & $\mathbf{V}_{\mathbf{3}}$ & $\mathbf{V}_{\mathbf{4}}$ \\
\hline Route length [km] & 32.455 & 32.010 & 32.605 & 39.800 \\
\hline Number of stations & 6 & 4 & 6 & 5 \\
\hline Length of open railway [km] & 24.920 & 23.580 & 23.165 & 34.640 \\
\hline Length of station railway tracks [km] & 6.850 & 3.950 & 6.550 & 6.600 \\
\hline Tunnel length [km] & 3.450 & 6.100 & 7.500 & 1.850 \\
\hline Bridge length [km] & 4.195 & 2.330 & 1.805 & 3.310 \\
\hline
\end{tabular}

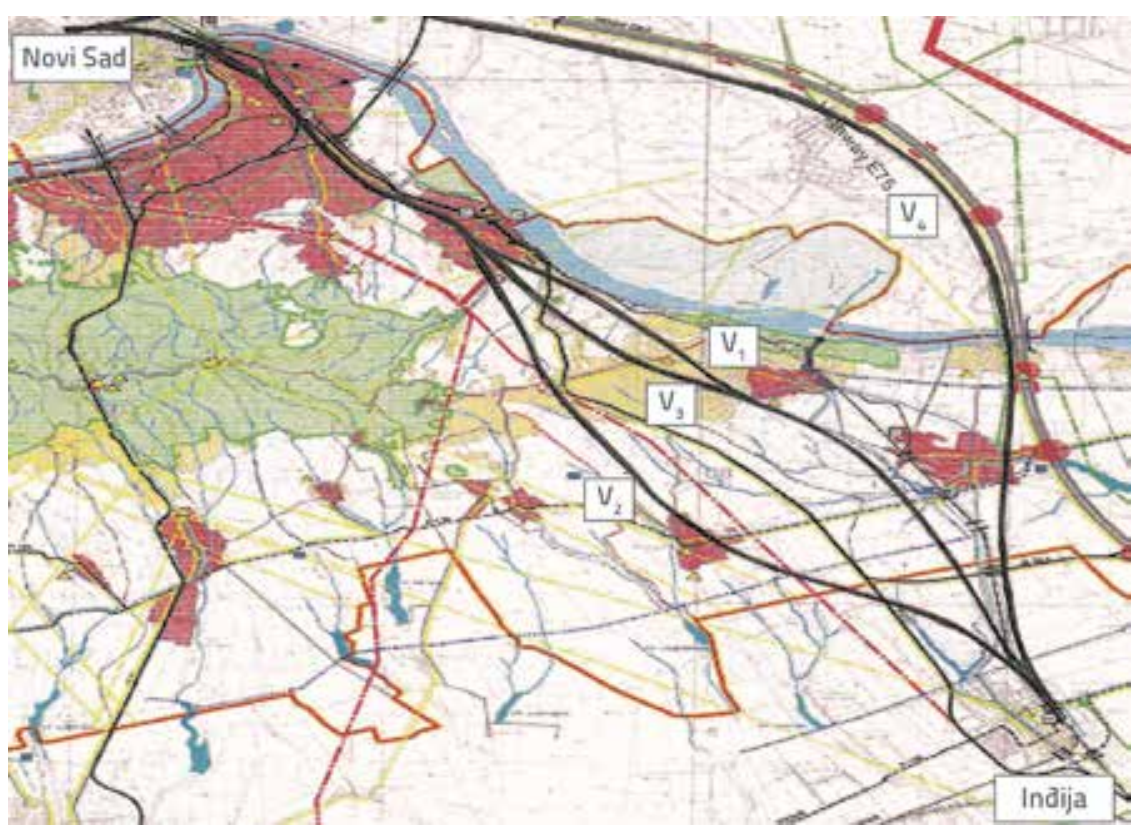

Figure 2. Railway route variant solutions

- Variant $\mathbf{V}_{\mathbf{4}}$ - Kovilj: it leaves the corridor of the existing railway in front of Beška, then turns right and descends by the tunnel, crosses the Danube via bridge, and runs along the corridor of the Belgrade-Subotica highway. It enters the Novi Sad station via the bridge over the Danube - Tisa - Danube Channel. The length of this route is $39,800 \mathrm{~km}$.

Other characteristics of these solutions are provided in Table 2.

\subsection{Evaluation and ranking of variant solutions}

In the further iterative optimization procedure, variant solutions are assessed and evaluated on the basis of: investment needed for construction of the route, cost of route management and maintenance, capacity of the route (throughput), impacts and consequences on spatial development, and impact on living environment. This assessment and evaluation is based on the adopted list of quantitative-economic, quantitative, technical and qualitative criteria and corresponding criteria functions . This list consists of the following criteria:
$\boldsymbol{K}_{1}$ - Investment needed for construction of the route is expressed in monetary units and includes investment needed for construction of open railway sections, stations, electrical traction devices, and investment for SS (signalling) and TK (telecommunication) devices.

$K_{2}$ - Cost of route management and maintenance is shown in monetary units annually and includes the costs for maintenance of railways, stations, electrical traction devices, SS and TK devices and the costs of organizing traffic and management.

$\boldsymbol{K}_{3}$ - Capacity - route throughput represents the number of pairs of trains, and/or the number of trains that can pass along the route during the observed period of time.

$\boldsymbol{K}_{\mathbf{4}}$-Impact on spatial development is evaluated by allocating points, and refers to preservation of spatial units, occupation of agricultural and construction land, and preservation of cultural and historical heritage.

$\boldsymbol{K}_{5}$-Impact on living environment is evaluated by allocation points and refers to the influence of noise and vibration, impact on soil, water resources, flora and fauna, climate, and microclimate.

The proposed criteria are presented through the corresponding criteria functions $f_{i{ }^{\prime}}$ which are calculated using the methodology defined in paper [6], and the evaluation process is carried out by individually evaluating each variant according to each criterion, i.e. by determining the criteria function for each variant. Since there is indeterminacy in the estimation of criteria functions for each variant solution, i.e. since functions are not expressed in numerical values, but in a triplet of values: lowest value, modal-most promising value and highest possible value, this problem can be overcome by applying triangular fuzzy numbers, and criteria functions are displayed in the following form $f_{i j}=\left(l_{i, j^{\prime}} m_{i, j^{\prime}} r_{i, j}\right)$. In this order of criteria functions, the functions $f_{1^{\prime}}$ $f_{2}, f_{4}$ and $f_{5}$ have a minimizing effect, while the function has a maximizing effect. The results gained by assessing values of proposed variant solutions become the elements of the initial decision-making matrix $F_{i,}$ and are shown in Table 3.

As the criteria functions have different measurement units, the initial matrix for decision-making $F_{i j}$ (Step 1 and Step 2 of the fuzzy VIKOR method) was normalized. For realization of the ranking procedure, it is necessary to assign fuzzy weights coefficients $\tilde{w}_{i}$ to all criteria and to determine fuzzy measures of deviation $\tilde{S}_{j}$ and $\tilde{R}_{j}$ of variants from ideal solutions (Step 3). Non-normalized values in 
Table 3. Initial decision-making matrix

\begin{tabular}{|c|c|c|c|c|c|c|c|}
\hline \multirow{2}{*}{ Criteria and criteria functions } & & & & \multicolumn{4}{|c|}{ Variant solution } \\
\hline & & & & V1 & V2 & V3 & V4 \\
\hline \multirow{3}{*}{ K1 - Investments for route construction } & \multirow{3}{*}{$\tilde{f}_{1}\left(10^{6} €\right)$} & \multirow{3}{*}{$\min$} & I & 212.12 & 223.05 & 250.05 & 229.88 \\
\hline & & & $\mathrm{m}$ & 212.12 & 223.05 & 250.05 & 229.88 \\
\hline & & & $r$ & 222.73 & 234.20 & 262.55 & 241.37 \\
\hline \multirow{3}{*}{$\begin{array}{l}\mathrm{K} 2 \text { - Costs of route management and } \\
\text { maintenance }\end{array}$} & \multirow{3}{*}{$\tilde{f}_{2}\left(10^{6} € /\right.$ god $)$} & \multirow{3}{*}{$\min$} & I & 19.19 & 18.62 & 18.81 & 22.42 \\
\hline & & & $\mathrm{m}$ & 20.20 & 19.60 & 19.80 & 23.60 \\
\hline & & & $r$ & 21.21 & 20.58 & 20.79 & 24.78 \\
\hline \multirow{3}{*}{ K3 - Capacity-route throughput } & \multirow{3}{*}{$\tilde{f}_{3}$ (pari vlakova) } & \multirow{3}{*}{$\max$} & I & 106.00 & 107.00 & 106.00 & 103.00 \\
\hline & & & $\mathrm{m}$ & 106.00 & 107.00 & 106.00 & 103.00 \\
\hline & & & $r$ & 106.00 & 107.00 & 106.00 & 103.00 \\
\hline \multirow{3}{*}{ K4 - Effects of route on spatial development } & \multirow{3}{*}{$\tilde{f}_{4}$ (bodova) } & \multirow{3}{*}{$\min$} & I & 33.25 & 34.20 & 28.50 & 41.80 \\
\hline & & & $\mathrm{m}$ & 35.00 & 36.00 & 30.00 & 44.00 \\
\hline & & & $r$ & 36.75 & 37.80 & 31.50 & 46.20 \\
\hline \multirow{3}{*}{ K5 - Effects on living environment } & \multirow{3}{*}{$\tilde{f}_{5}$ (bodova) } & \multirow{3}{*}{$\min$} & 1 & 17.10 & 11.40 & 10.45 & 7.60 \\
\hline & & & $\mathrm{m}$ & 18.00 & 12.00 & 11.00 & 8.00 \\
\hline & & & & 18.90 & 12.60 & 11.55 & 8.40 \\
\hline
\end{tabular}

the form of integers ranging from 1 to 3 were adopted for weight coefficients of all criteria, and five possible value scenarios were proposed. Non-normalized values of weight coefficients for the proposed possible scenarios are shown in Table 4.

Table 4. Proposed values of weight coefficients

\begin{tabular}{|c|c|c|c|c|c|}
\hline \multirow{2}{*}{$\begin{array}{c}\text { Weight } \\
\text { coefficients }\end{array}$} & \multicolumn{5}{|c|}{ Scenarios } \\
\cline { 2 - 6 } & SCI & SC II & SC III & SC IV & SC V \\
\hline$\tilde{w}_{1}$ & $(1,1,1)$ & $(3,3,3)$ & $(3,3,3)$ & $(2,2,2)$ & $(2,2,2)$ \\
\hline$\tilde{w}_{2}$ & $(1,1,1)$ & $(3,3,3)$ & $(3,3,3)$ & $(2,2,2)$ & $(2,2,2)$ \\
\hline$\tilde{w}_{3}$ & $(1,1,1)$ & $(3,3,3)$ & $(2,2,2)$ & $(3,3,3)$ & $(2,2,2)$ \\
\hline$\tilde{w}_{4}$ & $(1,1,1)$ & $(2,2,2)$ & $(1,1,1)$ & $(1,1,1)$ & $(3,3,3)$ \\
\hline$\tilde{w}_{5}$ & $(1,1,1)$ & $(2,2,2)$ & $(1,1,1)$ & $(1,1,1)$ & $(3,3,3)$ \\
\hline
\end{tabular}

The first scenario (SC $\downarrow$ ) envisages an equal importance of all criteria and, therefore, the criteria have the same weight coefficients. In the second scenario (SC II), an equal priority

a) $\mu(x)$

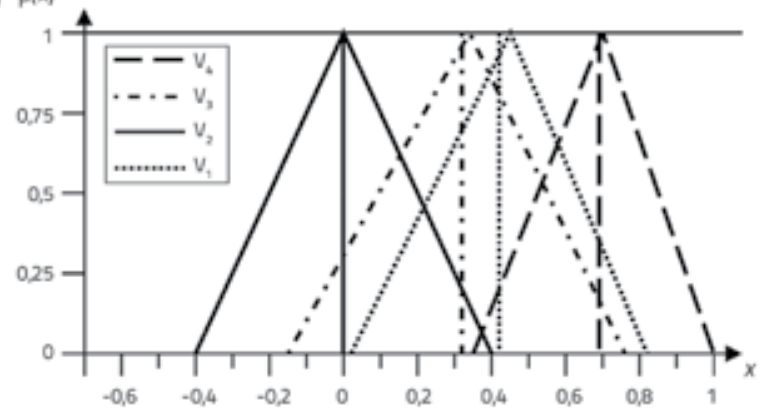

is given to economic and traffic aspects, and so the weight coefficients of these criteria are somewhat greater. In the third scenario (SC III), priority is primarily given to economic criteria, while in the fourth scenario (SC M priority is given to the traffic aspect. In the fifth scenario (SC $V$, the problem of ranking is considered from a spatial-environmental aspect, giving preference primarily to the effects on spatial development and environment. As in paper [6], the reason for defining these scenarios is to check stability of variants on ranking lists.

Fuzzy measures of deviation of variants from ideal solutions were determined according to the weight adopted in the decision-making strategy by the "majority of criteria" of $\vartheta=$ 0.5. Their values are shown in Table 5, while Figure 3 shows the values of $\tilde{Q}_{j}$ for the first two weight coefficient scenarios (Step 4). After defuzzification of values $\widetilde{Q S}, \widetilde{Q R}$ and $\tilde{Q}$ (Step 5), the final decision-making matrix and ranking lists are made for measures of deviation and, as shown in Table 6 and Table 7. Figure 4 shows strategic stability of measures of deviation and in the example of the first and second scenarios. The ranking was achieved by decreasing values for each deviation measure (Step 6).

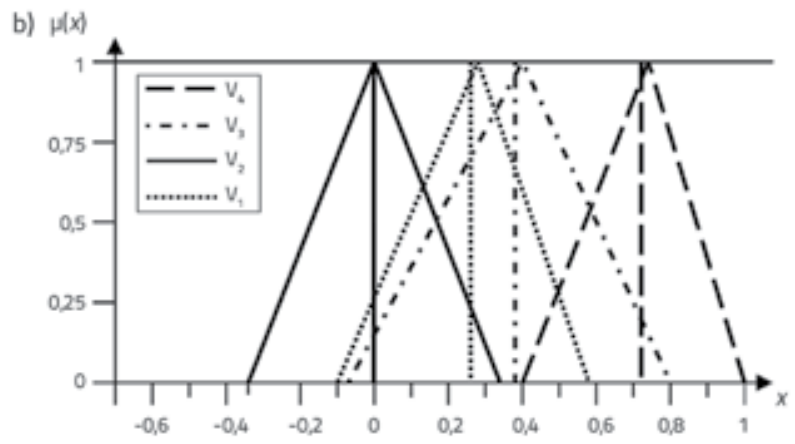

Figure 3. Fuzzy deviations $\tilde{Q}_{j}$ of variants from ideal solutions and their defuzzified values: a) first scenario (SC I); b) second scenario (SC II) 
Table 5. Deviations $\widetilde{Q S}, \widetilde{Q R}$ and $\tilde{Q}$

\begin{tabular}{|c|c|c|c|c|c|c|c|c|c|c|c|c|c|}
\hline \multirow{3}{*}{\multicolumn{2}{|c|}{ Scenarios }} & \multicolumn{12}{|c|}{ Variant solution } \\
\hline & & \multicolumn{3}{|c|}{$v_{1}$} & \multicolumn{3}{|c|}{$v_{2}$} & \multicolumn{3}{|c|}{$V_{3}$} & \multicolumn{3}{|c|}{$V_{4}$} \\
\hline & & 1 & $m$ & $r$ & 1 & $m$ & $r$ & 1 & $m$ & $r$ & I & $m$ & $r$ \\
\hline \multirow{3}{*}{$S C I$} & $\widetilde{Q S}$ & -0.294 & 0.171 & 0.632 & -0.456 & 0.000 & 0.456 & -0.341 & 0.110 & 0.568 & 0.064 & 0.531 & 1.000 \\
\hline & $\widetilde{Q R}$ & 0.333 & 0.723 & 1.000 & -0.354 & 0.000 & 0.354 & 0.022 & 0.542 & 1.000 & 0.646 & 0.880 & 1.000 \\
\hline & $\tilde{Q}$ & 0.020 & 0.447 & 0.816 & -0.405 & 0.000 & 0.405 & -0.159 & 0.326 & 0.784 & 0.355 & 0.705 & 1.000 \\
\hline \multirow{3}{*}{$S C I I$} & $\widetilde{Q S}$ & -0.303 & 0.134 & 0.568 & -0.431 & 0.000 & 0.431 & -0.267 & 0.160 & 0.596 & 0.114 & 0.556 & 1.000 \\
\hline & $\widetilde{Q R}$ & 0.092 & 0.430 & 0.595 & -0.317 & 0.000 & 0.317 & 0.126 & 0.627 & 1.000 & 0.683 & 0.928 & 1.000 \\
\hline & $\tilde{Q}$ & -0.106 & 0.282 & 0.582 & -0.374 & 0.000 & 0.374 & -0.070 & 0.394 & 0.798 & 0.399 & 0.742 & 1.000 \\
\hline \multirow{3}{*}{ SC III } & $\widetilde{Q S}$ & -0.381 & 0.074 & 0.525 & -0.451 & 0.000 & 0.451 & -0.235 & 0.213 & 0.672 & 0.072 & 0.535 & 1.000 \\
\hline & $\widetilde{Q R}$ & -0.179 & 0.085 & 0.364 & -0.364 & 0.000 & 0.383 & 0.133 & 0.587 & 1.000 & 0.270 & 0.493 & 1.000 \\
\hline & $\tilde{Q}$ & -0.280 & 0.080 & 0.445 & -0.407 & 0.000 & 0.417 & -0.051 & 0.400 & 0.836 & 0.171 & 0.514 & 1.000 \\
\hline \multirow{3}{*}{ SCIV } & $\widetilde{Q S}$ & -0.233 & 0.133 & 0.495 & -0.361 & 0.000 & 0.361 & -0.163 & 0.196 & 0.562 & 0.257 & 0.628 & 1.000 \\
\hline & $\widetilde{Q R}$ & -0.038 & 0.165 & 0.268 & -0.223 & 0.000 & 0.223 & 0.076 & 0.391 & 0.634 & 0.776 & 0.938 & 1.000 \\
\hline & $\tilde{Q}$ & -0.136 & 0.149 & 0.382 & -0.292 & 0.000 & 0.292 & -0.043 & 0.294 & 0.598 & 0.517 & 0.783 & 1.000 \\
\hline \multirow{3}{*}{ SC V } & $\widetilde{Q S}$ & -0.282 & 0.218 & 0.714 & -0.489 & 0.000 & 0.489 & -0.435 & 0.046 & 0.534 & 0.000 & 0.499 & 1.000 \\
\hline & $\widetilde{Q R}$ & 0.332 & 0.722 & 1.000 & -0.353 & 0.000 & 0.353 & -0.223 & 0.200 & 0.546 & 0.192 & 0.594 & 1.000 \\
\hline & $\tilde{Q}$ & 0.333 & 0.723 & 1.000 & -0.354 & 0.000 & 0.354 & -0.224 & 0.201 & 0.546 & 0.192 & 0.595 & 1.000 \\
\hline
\end{tabular}

Table 6. Decision-making matrices based on deviations and after defuzzification

\begin{tabular}{|c|c|c|c|c|c|c|c|c|c|}
\hline \multirow{3}{*}{\multicolumn{2}{|c|}{ Scenarios }} & \multicolumn{8}{|c|}{ Variant solution } \\
\hline & & \multicolumn{2}{|c|}{$V_{1}$} & \multicolumn{2}{|c|}{$v_{2}$} & \multicolumn{2}{|c|}{$V_{3}$} & \multicolumn{2}{|c|}{$v_{4}$} \\
\hline & & \multirow{2}{*}{$\begin{array}{c}\text { def. value } \\
0.170\end{array}$} & \multirow{2}{*}{$\begin{array}{c}\text { rank } \\
3\end{array}$} & \multirow{2}{*}{$\begin{array}{c}\text { def. value } \\
0.000\end{array}$} & \multirow{2}{*}{$\begin{array}{c}\text { rank } \\
1\end{array}$} & \multirow{2}{*}{$\begin{array}{c}\text { def. value } \\
0.112\end{array}$} & \multirow{2}{*}{$\begin{array}{c}\text { rank } \\
2\end{array}$} & \multirow{2}{*}{$\begin{array}{c}\text { def. value } \\
0.532\end{array}$} & \multirow{2}{*}{$\begin{array}{c}\text { rank } \\
4\end{array}$} \\
\hline \multirow{3}{*}{ SCI } & QS & & & & & & & & \\
\hline & QR & 0.695 & 3 & 0.000 & 1 & 0.527 & 2 & 0.851 & 4 \\
\hline & $\mathrm{Q}$ & 0.432 & 3 & 0.000 & 1 & 0.319 & 2 & 0.691 & 4 \\
\hline \multirow{3}{*}{ SC II } & QS & 0.134 & 2 & 0.000 & 1 & 0.162 & 3 & 0.557 & 4 \\
\hline & QR & 0.387 & 2 & 0.000 & 1 & 0.595 & 3 & 0.885 & 4 \\
\hline & $\mathrm{Q}$ & 0.260 & 2 & 0.000 & 1 & 0.379 & 3 & 0.721 & 4 \\
\hline \multirow{3}{*}{ SC III } & QS & 0.073 & 2 & 0.000 & 1 & 0.216 & 3 & 0.535 & 4 \\
\hline & QR & 0.089 & 2 & 0.000 & 1 & 0.577 & 4 & 0.564 & 3 \\
\hline & $\mathrm{Q}$ & 0.081 & 2 & 0.000 & 1 & 0.396 & 3 & 0.550 & 4 \\
\hline \multirow{3}{*}{ SCIV } & QS & 0.132 & 2 & 0.000 & 1 & 0.198 & 3 & 0.628 & 4 \\
\hline & QR & 0.140 & 2 & 0.000 & 1 & 0.373 & 3 & 0.913 & 4 \\
\hline & $Q$ & 0.136 & 2 & 0.000 & 1 & 0.286 & 3 & 0.771 & 4 \\
\hline \multirow{3}{*}{$S C V$} & QS & 0.217 & 3 & 0.000 & 1 & 0.047 & 2 & 0.499 & 4 \\
\hline & QR & 0.695 & 4 & 0.000 & 1 & 0.181 & 2 & 0.596 & 3 \\
\hline & $\mathrm{Q}$ & 0.456 & 3 & 0.000 & 1 & 0.114 & 2 & 0.548 & 4 \\
\hline
\end{tabular}


Table 7. Ranking lists of route variants for proposed scenarios and $\vartheta=0,5$

\begin{tabular}{|c|c|c|c|c|}
\hline \multirow{2}{*}{ Scenarios } & \multicolumn{4}{|c|}{ Rank } \\
\cline { 2 - 5 } & $\mathbf{1}$ & $\mathbf{2}$ & $\mathbf{3}$ & $\mathbf{4}$ \\
\hline SCI & $\mathbf{V}_{2}(0.000)$ & $\mathbf{V}_{3}(0.319)$ & $\mathbf{V}_{1}(0.432)$ & $\mathbf{V}_{4}(0.691)$ \\
\hline SC II & $V_{2}(0.000)$ & $V_{1}(0.260)$ & $V_{3}(0.379)$ & $V_{4}(0.721)$ \\
\hline$S C I I I$ & $V_{2}(0.000)$ & $V_{1}(0.081)$ & $V_{3}(0.396)$ & $V_{4}(0.550)$ \\
\hline$S C I V$ & $V_{2}(0.000)$ & $V_{1}(0.136)$ & $V_{3}(0.286)$ & $V_{4}(0.771)$ \\
\hline$S C V$ & $V_{2}(0.000)$ & $V_{3}(0.114)$ & $V_{1}(0.456)$ & $V_{4}(0.548)$ \\
\hline
\end{tabular}

\subsection{Analysis of results}

The last step in the fuzzy VIKOR method (Step 7) is the proposal of a compromise solution, and final decision-making about the most favourable variant solution. The results of the multicriteria ranking carried out with the fuzzy VIKOR method (Table 7) show that variant $V_{2}$ is always ranked first for each weight coefficient value scenario. In the case where priority is given to economic, traffic or environmental criteria, a set of compromise solutions is defined, and these are variant $V_{2}$ and variant $V_{1}$ i.e. variant $V_{2}$ and variant $V_{3}$. The results obtained in this way will be offered to the decision-makers in the decision-making process for selection of the railway route on the section between Indija and Novi Sad railway stations. Which of these solutions will be selected by decision-makers depends on the scenarios they decide to accept. The variant Maradik $\left(V_{2}\right)$ is proposed for the scenarios SC I and SC II as a compromise solution because conditions U1 (sufficient advantage) and U2 (sufficient stability) are met (Figure 4).
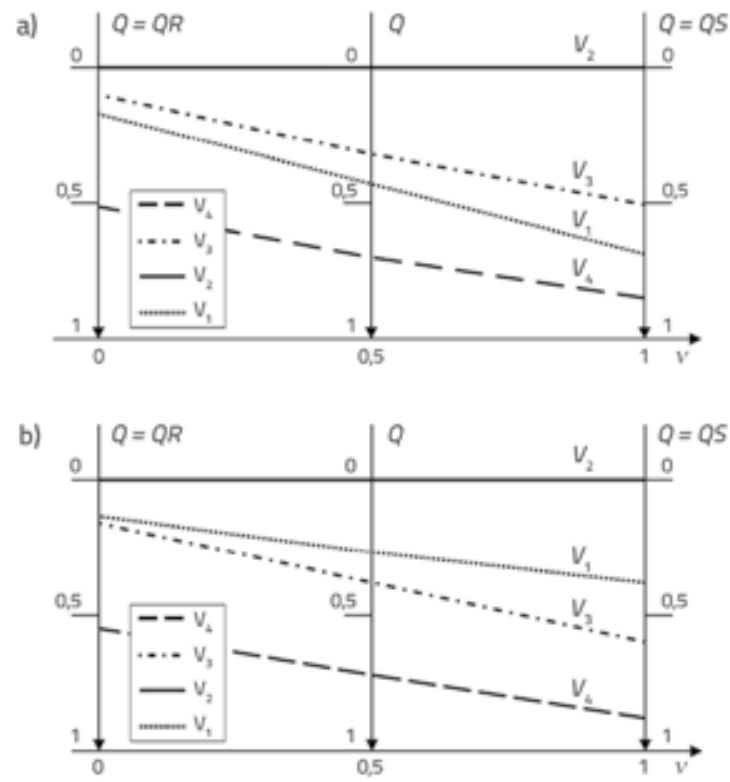

Figure 4. Stability and based on weight factor of decision-making strategy 9: a) first scenario (SC I); b) second scenario (SC II)

In the case of scenarios SC III and SC IV, a set of compromise solutions involving variants Maradik $\left(V_{2}\right)$ and Čortanovci $\left(V_{1}\right)$ is proposed, and in the case of SC Vscenarios, a set of compromise solutions involving variants Maradik $\left(V_{2}\right)$ and Combined $\left(V_{3}\right)$ is proposed. In the cases of these scenarios (SC III, SC IV and SC V the condition $U 2$ is fulfilled, while the condition $U 1$ is not fulfilled. For this reason, variant solutions from a set of compromise solutions should additionally be analysed, and ranking should be repeated in order to obtain the final compromise solution.

\section{Conclusion}

An approach to fuzzy multicriteria decision-making in the process of railway infrastructure planning and design is presented in the paper. Regardless of whether the construction of new or reconstruction of the existing facilities is envisaged, the process of multicriteria decision-making in the planning and design process involves definition of the problem and generation of variant solutions, which is followed by their evaluation and selection of the most favourable solution. When evaluating variant solutions, it is necessary to take into account investment costs, exploitation characteristics and functionality, as well as the broader socioeconomic context taking into account external effects. In these circumstances, the methods of multicriteria decision-making have proven to be suitable for finding the best or least harmful variants compared to the defined criteria and their weights. The methods used in the existing literature for evaluating and ranking transport infrastructure projects (railway or road projects) are based on the assumption of attribute certainty, i.e. on the already formed set of acceptable variant solutions and on precisely defined criteria and criteria functions. On the other hand, the decision-making problem in evaluating variant solutions on infrastructure projects is most often characterized by criteria that can neither be clearly (precisely) quantified by the criteria function nor represented with a single numerical value for each variant solution.

In this regard, the newly introduced approach is based on the theory of fuzzy sets and allows finding a comprehensive and systematic solution to the problem of uncertainty and indeterminacy in the assessment of criteria functions. The proposed multicriteria decision-making approach is presented in the scope of methodology for evaluating and selecting the most favourable route of a railway line. The variants of the route are generated in the method by different values of structural and exploitation parameters of the system, while the assessment and evaluation are performed using several criteria functions (investment needed for construction of the route, the cost of route operation and maintenance, the route capacity, the effects of the route on spatial development, and the route impact on the environment) with the use of fuzzy numbers, which is much more favourable and accurate compared to point values. The approach of compromise ranking in fuzzy environment, i.e. the fuzzy VIKOR method, is applied for the ranking of variant solutions. Several weight coefficient scenarios enabled verification of the stability of variants in ranking lists. The ultimate result of fuzzy multicriteria decision-making is the proposal of the route, and it should represent the best solution from a set of acceptable solutions defined in accordance with the adopted criteria and real constraints. 
If we compare the results obtained in this paper with those obtained by using the traditional multicriteria procedure presented in [6], it can be observed that the order of proposed variant solutions on the ranking lists and in the new fuzzy conditions does not change. The obtained results were verified and the correctness of the proposed approach, including its practical usability in solving route selection problems, was demonstrated. The applied methodology and the fuzzy approach to multicriteria decision-making can be used by decision-makers for reaching final decisions, and can also be successfully applied on other transport infrastructure

\section{REFERENCES}

[1] Banai, R.: Public transportation decision-making: a case analysis of the Memphis Light Rail Corridor and route selection with Analytic Hierarchy Process, Journal of Public Transportation, 9 (2006) 2, pp. 1-24.

[2] Barić, D., Pilko, H., Strujić, J.: An Analytic Hierarchy Process model to evaluate road section design, Transport, 31 (2016) 3, pp. 312321.

[3] Sarrazin, R., De Smet, Y.: Applying multicriteria decision analysis to design safe road projects, European Journal of Transport and Infrastructure Research, 15 (2015) 4, pp. 613-634.

[4] Krpan, L., Vilke, S., Milković, M.: A model of the selection of an optimal railroad route by applying the multiple-criteria analysis, Tehnički vjesnik, 24 (2017) 4, pp. 1155-1164.

[5] Anton, J.M., Grau, J.B.: Madrid-Valencia high-speed rail line: a route selection, Proceedings of the Institution of Civil Engineers - Transport, 157 (2004) 3, pp. 153-161.

[6] Kosijer, M., Ivic, M., Markovic, M., Belosevic, I.: Multicriteria decision-making in railway route planning and design, Gradevinar, 64 (2012) 3, pp. 195-205.

[7] Kelly, C., Laird, J., Costantini, S., Richards, P., Carbajo, J., Nellthorp, J.: Ex post appraisal: What lessons can be learnt from EU cohesion funded transport projects?, Transport Policy, 37 (2015), pp. 8391.

[8] Zadeh, L.A.: Fuzzy sets, Information and Control, 8 (1965) 3, pp. 338-353.

[9] Colorni, A., Laniado, E., Muratori, S.: Decision support systems for environmental impact assessment of transport infrastructures, Transportation Research Part D: Transport and Environment, 4 (1999) 1, pp. 1-11.

[10] Tudela, A., Akiki, N., Cisternas, R.: Comparing the output of cost benefit and multi-criteria analysis, Transportation Research Part A: Policy and Practice, 40 (2006) 5, pp. 414-423.

[11] Elhorst, J. P., Oosterhaven, J.: Integral cost-benefit analysis of Maglev projects under market imperfections, Journal of Transport and Land Use, 1 (2008) 1, pp. 65-87.

[12] Tsamboulas, D.A.: A tool for prioritizing multinational transport infrastructure investments, Transport Policy, 14 (2007) 1, pp. 1126.

[13] Teng, J.Y., Huang, W. C., Lin, M.C.: Systematic budget allocation for transportation construction projects: a case in Taiwan, Transportation, 37 (2010) 2, pp. 331-361. facilities for ranking and selecting the most favourable variant solution.

\section{Acknowledgments}

This paper was prepared with the support of the Ministry of Education and Science of the Republic of Serbia in the scope of the technological project No. 36012: "Exploring technicaltechnological, human resources and organizational capacities of the Serbian Railways from the aspect of present and future requirements of the European Union".

[14] De Neufville, R., Keeney, R.L.: Multiattribute preference analysis for transportation systems evaluation, Transportation Research, 7 (1973) 1, pp. 63-76

[15] Saaty, T.L.: Scenarios and priorities in transport planning: Application to the Sudan, Transportation Research, 11 (1977) 5 pp. 343-350.

[16] Roy, B., Hugonnard, J.C.: Ranking of suburban line extension projects on the Paris Metro System by a multicriteria method, Transportation Research Part A: General, 16 (1982) 4, pp. 301 312 .

[17] Giuliano, G.: A multicriteria method for transportation investment planning, Transportation Research Part A: General, 19 (1985) 1, pp. 29-41.

[18] Roy, B., Présent, M., Silhol, D.: A programming method for determining which Paris metro stations should be renovated, European Journal of Operational Research, 24 (1986) 2, pp. 318334.

[19] Cook, W.D., Golan, I., Kazakov, A., Kress, M.: A case study of a non-compensatory approach to ranking transportation projects, Journal of the Operational Research Society, 39 (1988) 10, pp. 901-910.

[20] Kalamaras, G.S., Brino, L., Carrieri, G., Pline, C., Grasso, P.: Application of multicriteria analysis to select the best highway alignment, Tunnelling and Underground Space Technology, 15 (2000) 4, pp. 415-420.

[21] Banai, R.: Evaluation of land use-transportation systems with the Analytic Network Process, Journal of Transport and Land Use, 3 (2010) 1, pp. 85-112.

[22] Hamurcu, M., Eren, T.: A multicriteria decision-making for monorail route selection in Ankara, International Journal of Industrial Electronics and Electrical Engineering, 4 (2016) 5, pp. 121-125.

[23] Barić, D., Pižeta, F.: An AHP model for level crossing design, International Journal of Safety and Security Engineering, 8 (2018) 1, pp. 65-76.

[24] Saat, M.R., Aguilar Serrano, J.: Multicriteria high-speed rail route selection: application to Malaysia's high-speed rail corridor prioritization, Transportation Planning and Technology, 38 (2015) 2, pp. 200-213.

[25] Anton, J.M., Bielza, C.: Compromise-based approach to road project selection in Madrid Metropolitan Area, Journal of the Operations Research Society of Japan, 46 (2003) 1, pp. 99-122. 
[26] Belošević, I., Kosijer, M., Ivić, M., Pavlović, N.: Group decision making process for early stage evaluations of infrastructure projects using extended VIKOR method under fuzzy environment, European Transport Research Review, 10 (2018) 2, pp. 43.

[27] Keshkamat, S.S., Looijen, J.M., Zuidgeest, M.: The formulation and evaluation of transport route planning alternatives: a spatial decision support system for the Via Baltica project, Poland, Journal of transport geography, 17 (2009) 1, pp. 54-64.

[28] Kim, H.Y., Wunneburger, D., Neuman, M., An, S.Y.: Optimizing high-speed rail routes using a Spatial Decision Support System (SDSS): the Texas Urban Triangle (TUT) case, Journal of transport geography, 34 (2014), pp. 194-201.

[29] Karleuša, B., Dragičević, N., Deluka-Tibljaš, A.: Review of multicriteria-analysis methods application in decision making about transport infrastructure, Gradevinar, 65 (2013) 7, pp. 619631.

[30] Kabir, G., Sadiq, R., Tesfamariam, S.: A review of multi-criteria decision-making methods for infrastructure management, Structure and Infrastructure Engineering, 10 (2014) 9, pp. 11761210.

[31] Zavadskas, E.K., Antuchevičienè, J., Kapliński, O.: Multi-criteria decision making in civil engineering: Part I: a state of the art, Engineering Structures and Technologies, 7 (2015) 3, pp. 103113.

[32] Zavadskas, E.K., Antuchevičienè, J., Kapliński, O.: Multi-criteria decision making in civil engineering. Part II: Applications, Engineering Structures and Technologies, 7 (2015) 4, pp. 151167.
[33] Opricovic, S.: Višekriterijumska optimizacija sistema u građevinarstvu, Građevinski fakultet, Beograd, 1988.

[34] Opricovic, S., Tzeng, G. H.: Compromise solution by MCDM methods: A comparative analysis of VIKOR and TOPSIS, European Journal of Operational Research, 156 (2004) 2, pp. 445-455.

[35] Opricovic, S., Tzeng, G.H.: Extended VIKOR method in comparison with outranking methods, European Journal of Operational Research, 178 (2007) 2, pp. 514-529.

[36] Zeleny, M.: Multiple criteria decision making, Mc Graw-Hill, New York, 1982.

[37] Klir, G.J., Yuan, B.: Fuzzy sets and fuzzy logic: theory and applications, Prentice-Hall, New Jersey, 1995.

[38] Wang, L.X.: A course in fuzzy systems and control, Prentice-Hall, New Jersey, 1997.

[39] Zimmermann, H.J.: Fuzzy Set Theory - and its applications, Springer Science \& Business Media, New York, 2011.

[40] Opricovic, S.: Fuzzy VIKOR with an application to water resources planning, Expert Systems with Applications, 38 (2011) 10, pp. 12983-12990

[41] Opricovic, M.: VIKOR method with application to borrowing terms selection. In: Multiple Criteria Decision Making in Finance, Insurance and Investment, Springer International Publishing, Cham, pp. 205-227, 2015.

[42] Grupa autora: Studija podobnosti modernizacije železničke pruge Subotica-Beograd-Niš-Dimitrovgrad: Bankarski dosije, Saobraćajni institut CIP \& Sofrerail Pariz, Beograd, 1991. 